\title{
Diatom succession in an urban reservoir system
}

\author{
Christopher M. Donar ${ }^{1}$, Robert K. Neely ${ }^{2}$ \& Eugene F. Stoermer ${ }^{1}$ \\ ${ }^{1}$ Center for Great Lakes and Aquatic Sciences, University of Michigan, Ann Arbor, MI 48109, USA (E-mail: \\ Donar@Umich.edu) \\ ${ }^{2}$ Department of Biology, Eastern Michigan University, Ypsilanti, MI 48197, USA
}

Received 16 November 1994; accepted 17 October 1995

Key words: reservoir, diatom, core, sediments, hydrology, paleolimnology, eutrophication

\begin{abstract}
A $43 \mathrm{~cm}$ by $5 \mathrm{~cm}$ diameter sediment core sample was obtained from Ford Lake reservoir in Washtenaw County, Michigan, and sectioned at $1 \mathrm{~cm}$ intervals. The purpose of this study was to determine whether diatom communities in this reservoir have undergone quantifiable changes in abundance and composition since its creation. Thirty-one $\mathrm{cm}$ of this core appeared to represent material deposited since the creation of the reservoir based on changes in diatom abundance, the physical composition of the sediment and the change in biogenic $\mathrm{SiO}_{2}$ concentration. Fortyseven species of diatoms were identified total concentrations of diatom remains varied from $1 \times 10^{4} \mathrm{~g}^{-1}$ to $1 \times 10^{7}$ $\mathrm{g}^{-1}$. Prior to the establishment of the reservoir, the diatom flora was dominated by benthic taxa. Benthic diatoms were numerous throughout the entire core, but eutrophic taxa (e.g., Aulacoseira italica, Aulacoseira granulata, Stephanodiscus niagarae, Fragilaria crotonensis) dominated much of the core after the reservoir's creation. Total diatom density increased about tenfold in the about the first 10-15 years after the reservoir's creation before declining markedly.
\end{abstract}

\section{Introduction}

Reservoirs are engineered systems designed to retain water for agriculture, flood control, municipal drinking water or to generate hydroelectric power. Each of these uses, however, requires different management practices that have profound effects on the biological, physical and chemical characteristics of the reservoir system. Reservoirs differ from lakes in that they contain pumping mechanisms and discharge gates that influence the limnological conditions present in each reservoir; consequently the ability to manipulate several abiotic and biotic factors exists in these systems, but it is difficult to predict the response of phytoplankton communities to manipulations. In addition, because the response of phytoplankton communities to induced changes can occur over varying time scales, the rate of change in algal populations in response to extensive modifications in the reservoir ecosystem may not become manifest for several years (Alavarez-Cobelas \& Arauzo, 1994).
Paleolimnological studies have examined diatoms preserved in sediments to infer past trophic conditions (Carney, 1982; Dixit et al., 1992; Smol, 1987; Stoermer et al., 1985a). Ecological requirements for many freshwater diatoms have been compiled and diatoms are often excellent indicators of specific environmental conditions (Lowe, 1974). Paleolimnological techniques have long been applied to lakes, but not nearly as many studies have been performed on reservoir systems. With paleolimnological techniques, the rate of change and response of diatom communities to changing reservoir conditions can be established, thereby providing a basis for reconstructing the limnological history of a developing reservoir. For example, changes in diatom diversity, abundance and valve morphology may indicate nutrient enrichment (Stoermer, 1978; Stoermer et al., 1985b). Furthermore, changes in the proportions of benthic and planktonic diatoms may indicate fluctuations in water retention (Soballe \& Kimmel, 1987). 
Our understanding of reservoir dynamics can be enhanced by using diatoms as indicators of changing limnological conditions during the maturation of a reservoir. Thus, the purpose of this study was to determine whether diatom communities in a reservoir in southeastern Michigan, USA (Ford Lake reservoir) have undergone quantifiable changes in abundance and composition since its creation. Land use in the Ford Lake reservoir drainage basin is diverse including urban, rural and industrial activities. The reservoir has several documented cases of anthropogenic nutrient enrichment and industrial contamination.

\section{Materials and methods}

Study site

Ford Lake (T19 N, R15W, Sec 8) was created in 1932 and is part of the Huron River watershed. It has a surface area of 394 hectares, a maximum depth of $9.1 \mathrm{~m}$ and an average depth of $4.4 \mathrm{~m}$ (Fig. 1). Dissolved oxygen profiles of the Ford Lake reservoir indicate that throughout the reservoir and for most of the year, oxygen concentrations are above $7 \mathrm{mg} / \mathrm{l}$ to a depth of $2 \mathrm{~m}$ (Owen, 1991).

\section{Core sample preparation and analysis}

A $43 \mathrm{~cm}$ long, $5 \mathrm{~cm}$ diameter core sample was obtained with a KB core sampler on October 11, 1991 from Ford Lake, approximately 20 meters due west of the island near the reservoir's center (Fig. 1). The sample site is in the deepest part of the transitional zone where the greatest diversity of diatoms is likely to occur. The core was frozen and stored at $-4{ }^{\circ} \mathrm{C}$. During the sectioning process, the core was kept frozen to limit distortion from smearing and gas evolution. Samples were cut from the frozen core at $1 \mathrm{~cm}$ intervals. Forty three samples were weighed and dried at $95^{\circ} \mathrm{C}$ for 12 hours.

One gram of dried sample material was taken from each interval for diatom analysis. The hydrogen peroxide, potassium dichromate method was used to clean diatom sample material (Patrick \& Reimer, 1966). Sample material was rinsed in distilled water and allowed to settle for 12 hours repeatedly until the yellow dichromate color was removed. Diatom material was removed, the volume of liquid containing diatom material was recorded and one $\mathrm{ml}$ of liquid sample was placed on a $0.5 \mathrm{~mm}$ coverslip and allowed to air dry. Three coverslips were prepared for
Table 1. Dissolved oxygen concentrations ( $\mathrm{mg} \mathrm{1}^{-1}$ ) in Ford Lake at the core sample site averaged over all sampling dates for each depth from May 1990 through April 1991. (from Owen, 1991)

\begin{tabular}{lrl}
\hline Depth & $\mathrm{N}$ & $\begin{array}{l}\text { Dissolved } \\
\text { oxygen } \\
\left(\mathrm{mg} \mathrm{l}^{-1}\right)\end{array}$ \\
\hline 0 & 40 & 10.1 \\
1 & 40 & 9.8 \\
2 & 32 & 9.6 \\
3 & 30 & 9.4 \\
4 & 28 & 9.2 \\
5 & 20 & 8.6 \\
6 & 20 & 8.4 \\
7 & 19 & 8.0 \\
8 & 10 & 5.4 \\
9 & 4 & 5.4 \\
\hline
\end{tabular}

each $1 \mathrm{~cm}$ interval. Hyrax(B) was used as a mounting medium. Diatoms were identified and counted with a Leitz Ortholux microscope with a 1.32 numerical aperture and $1000 \times$ oil immersion lens. Enumeration techniques described by Glover (1982) were utilized during analysis. Random transects were enumerated completely until approximately 150 diatoms were counted. Between one and three transects were necessary to fulfill this requirement. Diatom valves and recognizable portions of valves were counted as one intact unit. Diatoms were identified by using standard taxonomic keys, including Hustedt (1930) and Patrick \& Reimer (1966).

Biogenic silica analysis was conducted on core intervals following the techniques described by Davis \& Simmons (1979) and the Braun-Lubbe, AutoAnalyzer II Method number 696-82.

\section{Results and discussion}

Reasonably accurate dating of a sediment core is essential for interpretation of limnological events represented by core stratigraphy. Unfortunately, we are unable to date this core using conventional techniques, i.e., Cs${ }^{137}$ or ${ }^{210} \mathrm{~Pb}$ dating; however, the Ford Lake core seems representative of a period extending from the present to a time period prior to the reservoir's establishment 


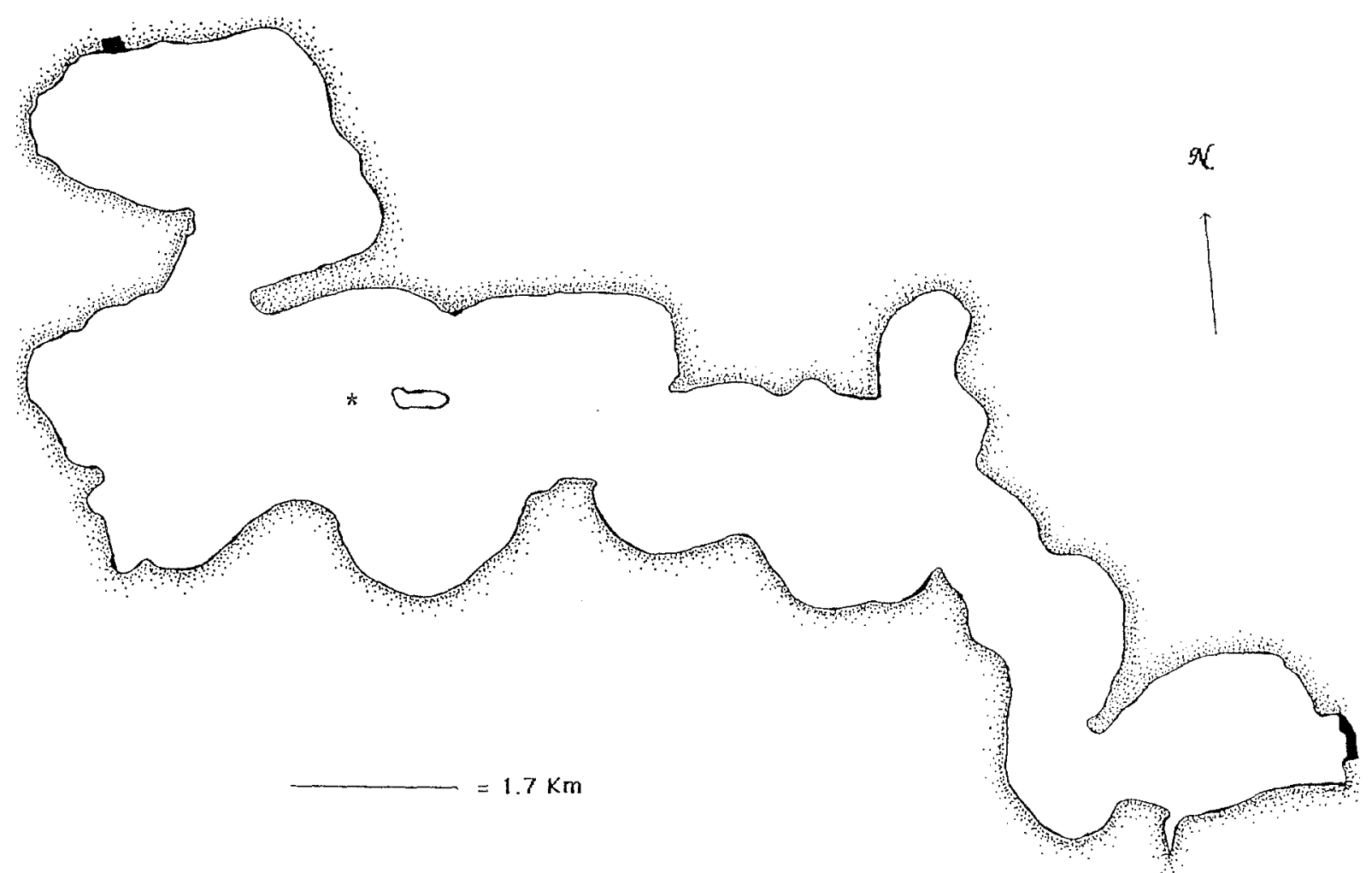

FORD LAKE RESERVOIR

WASHTENAW COUNTY MICHIGAN

Fig. 1. A map of Ford Lake reservoir. Asterisk indicates sample location.

(1932). This assumption is based on three observations. First, both benthic and planktonic diatoms increased at approximately the $31 \mathrm{~cm}$ interval (Fig. 2), an event very likely associated with increased algal productivity typical of reservoir creation (Baxter, 1977). Second, a gradual, modest increase in the concentration of biogenic silica in the 40-35 cm interval was punctuated by an abrupt increase in silica from approximately 10 to greater than $40 \mathrm{mg} \mathrm{kg}^{-1}$ of sediment near the $32 \mathrm{~cm}$ interval (Fig. 2). Clearly, the increased in silica is consistent with the increase in diatom remains found in the reservoir sediments. Third, two visibly different regions, 43 to $30 \mathrm{~cm}$ and $29 \mathrm{~cm}$ to surface, were evident in the core. The texture of material between 43 and $30 \mathrm{~cm}$ was a medium sand with dark grey silt. The $29 \mathrm{~cm}$ to surface region was characterized by fine light grey silt with some fine sand and did not display laminations; however, a lamination was clearly visible at the $30 \mathrm{~cm}$ depth. While we can never be absolutely certain without more specific dating techniques, these data suggest that the $30-32 \mathrm{~cm}$ interval corresponds to the creation of the reservoir, i.e., $30-32 \mathrm{~cm}$ of sediment have accumulated site in the 60 years since the reservoir's creation. Although sediment deposition in hydrologically dynamic systems such as reservoirs is extremely variable, Ford Lake seems to have experienced an average net-annual sedimentation rate of about $0.5 \mathrm{~cm} \mathrm{yr}^{-1}$ since its creation.

Forty-seven species of diatoms were identified from the Ford Lake core with total abundance ranging from a minimum of $\sim 1 \times 10^{4}$ diatoms $^{-1}$ in the $43 \mathrm{~cm}$ interval to $1 \times 10^{7}$ diatoms $^{-1}$ in the $25 \mathrm{~cm}$ interval (Fig. 2). Regions of the Ford Lake reservoir are evidently equally suited for the development of benthic and planktonic diatom flora (Fig. 2). In both absolute and relative abundance, benthic diatoms were generally more numerous in the $40-32 \mathrm{~cm}$ region of the core than in other regions (Fig. 2). In contrast, planktonic diatoms began to dominate at the $31-29 \mathrm{~cm}$ interval. Only in a few instances, e.g., 20,14, 7 and $4 \mathrm{~cm}$ intervals, did benthic diatom densities exceed planktonic diatom numbers. The more abundant species of 


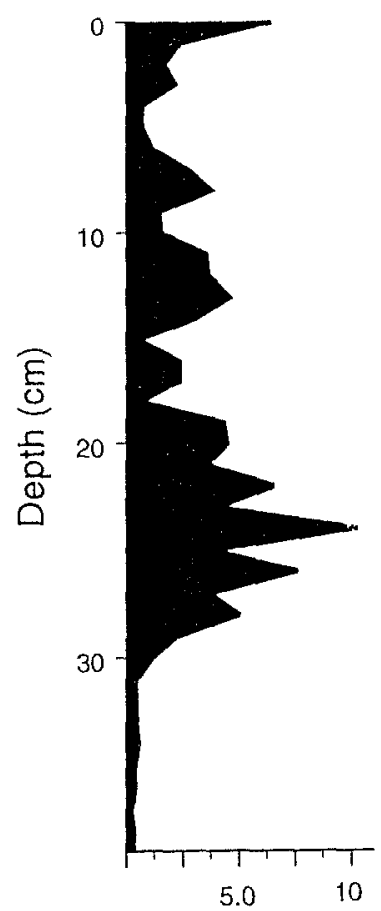

Total Diatom Density $\left(\times 10^{6}\right)$

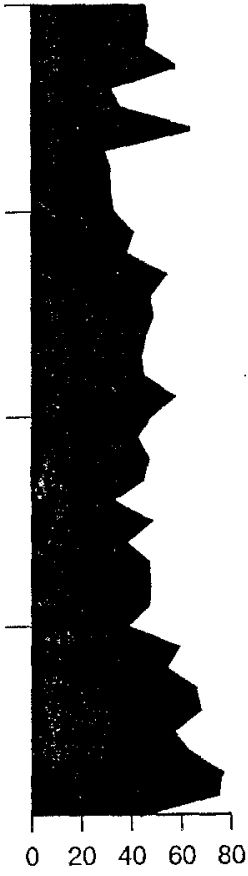

$\%$ Benthic

Diatoms

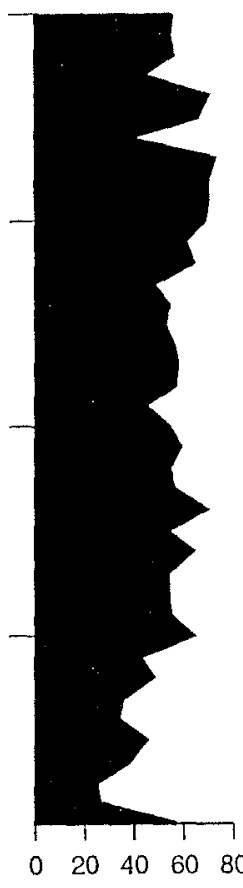

$\%$ Planktonic

Diatoms

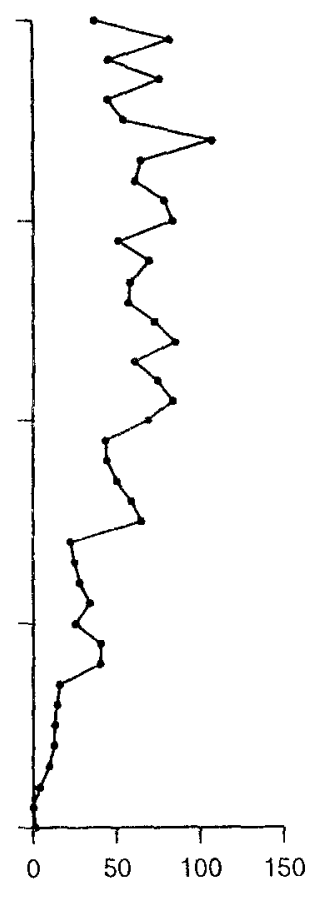

$\mathrm{mg} \mathrm{SiO} \mathrm{gm}^{-1}$

Fig. 2. The change in absolute density of diatoms (per gram of dry sediment), the percent composition of benthic and planktonic diatoms, and the biogenic silicon concentration in a $40 \mathrm{~cm}$ core from Ford Lake reservoir, Michigan, USA.

benthic diatoms were Fragilaria brevistriata Grun., Fragilaria vaucheriae (Kütz.) Peters, and Nitzschia spp. The morphometry of the reservoir and fluctuating water levels have no doubt contributed to the periodically high abundance of benthic diatoms. In particular, the northern portion of the reservoir (North Bay) may be acting as a source of benthic diatoms which are being deposited down reservoir. North Bay is characterized by shallow water ( $<2$ meters), as well as relative protection from wind and wave action; consequently, aquatic plants are abundant only in this region of the reservoir. Nutrient discharge from the Huron River impacts this area first and undoubtedly stimulates rich periphytic communities in the warm, shallow water. In addition, the Huron River may be a source of diatoms which are carried and deposited down reservoir, particularly during scouring events. For example, heavy rain storms in April 1968 resulted in flow rates $>6900$ cubic feet per second upstream of the reservoir, a flow so large that it caused the collapse of a bridge in a tributary of the Huron River just upstream of the reservoir. Clearly, such events are conducive to scour- ing, transport and deposition of materials, including diatoms, far into the reservoir.

The absolute and percent abundance of diatoms increased ten-fold at approximately the $31 \mathrm{~cm}$ interval (Figs 3 and 4). This pattern was observed for most species, particularly for planktonic taxa such as Aulacoseira italica (Ehrenb.) Simons., A. granulata (Ehrenb.) Simons., Stephanodiscus niagarae Ehrenb. and Diatoma vulgare Bory. (Figs 3 and 4). After this initial increase during the first 10 years of the reservoir's existence, diatom density declined precipitously in the 25 to $21 \mathrm{~cm}$ region (presumably the mid-1940's) of the core (Figs 3 and 4). Aulacoseira granulata, Cocconeis placentula Ehrenb., D. vulgare and others (Figs 3 and 4) are particularly exemplary of this pattern. If we are correct in our assessment that the $32 \mathrm{~cm}$ interval represents the creation of the reservoir, the interval from $32-25 \mathrm{~cm}$ corresponds to approximately the first 14 years after the reservoir's creation and a time period in which the reservoir rapidly became eutrophic. The creation of a reservoir produces a large body of water that is enriched with nutrients from newly submerged soil and decaying plant material. Of the 


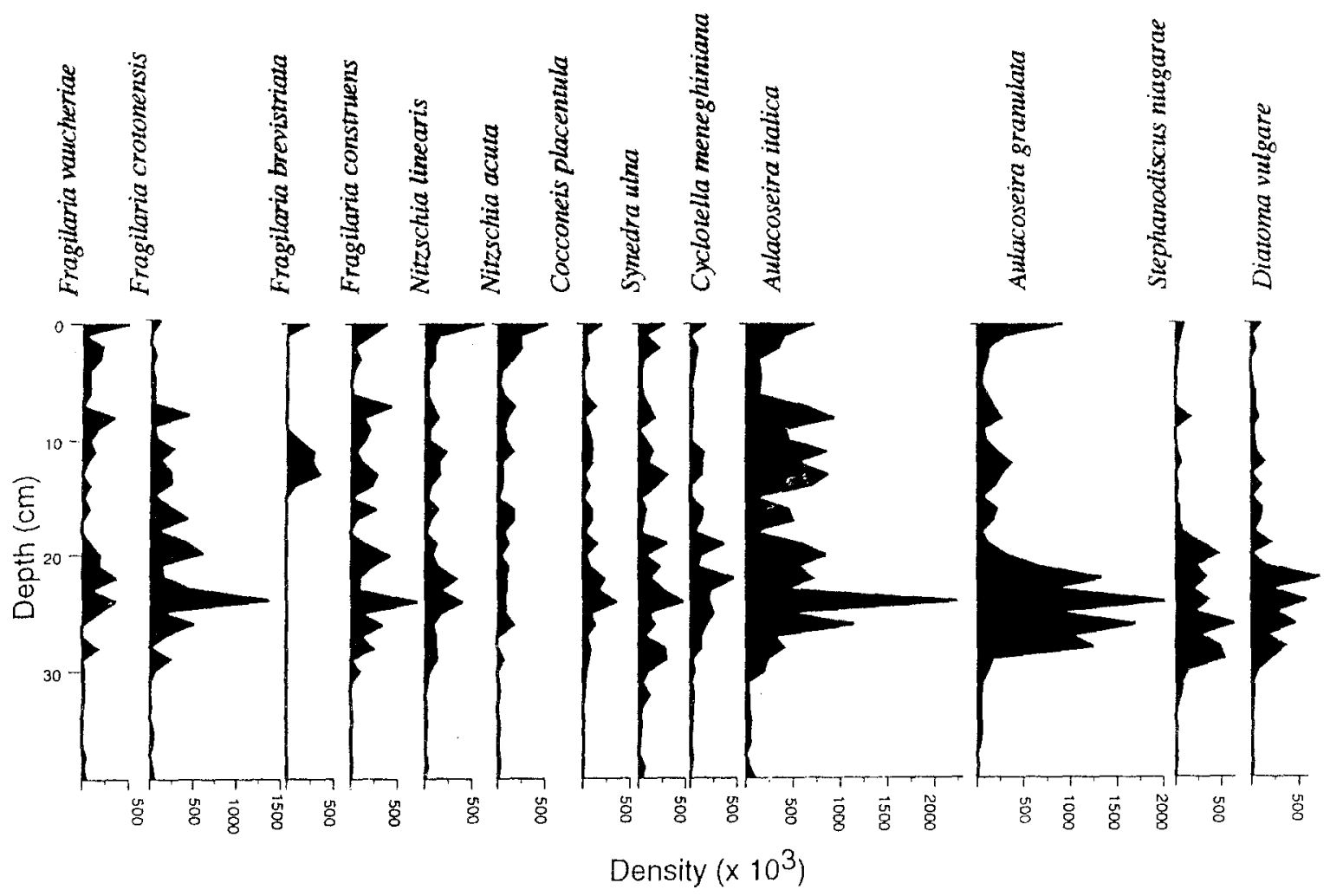

Fig. 3. The density (per gram of dry sediment) of diatom taxa in a $40 \mathrm{~cm}$ core from Ford Lake reservoir, Michigan, USA.

dominant planktonic species, S. niagara and Fragilaria crotonensis Kitt. are often associated with eutrophic conditions and increased dramatically before their eventual decline (Figs 3 and 4). Stephanodiscus niagara is particularly indicative of eutrophic waters in the Great Lakes region of North America (Stoermer, 1978).

The dramatic decline in planktonic diatoms, particularly taxa representative of eutrophic conditions, would suggest that nutrient concentrations and/or other conditions necessary for the growth of some diatom species changed with the reservoir's maturation. With respect to nutrients, in particular phosphorus, there is no reason to believe that concentrations declined. The Ypsilanti Wastewater Treatment Plant on the north shore of the Ford Lake reservoir was placed into service in 1935 and remained operational through 1982. As a result of discharge from the plant and run-off from other sources, the US Environmental Protection Agency estimated in 1975 that phosphorus loadings to Ford Lake were seven-fold higher than necessary to result in eutrophic conditions (USEPA, 1975), 44\% of phosphorus loading was attributable to discharge from the wastewater treatment plant. Today, phosphorus loads to Ford Lake remain high, about five fold higher than necessary to create eutrophic conditions (Owen, 1991). On the other hand, some species have remained relatively constant in density throughout the reservoir's existence, e.g., Nitzschia linearis (Ag.) W. Smith and C. placentula, while others have oscillated in abundance, e.g., F. construens (Ehrenb.) Grun., N. acuta Hantzsch. Consequently, it seems that at least phosphorus loading has been consistently high throughout Ford Lake's history and cannot be identified as the reason for the dramatic decline in diatoms in the $20-15 \mathrm{~cm}$ interval.

The decline in diatom density also seems unrelated to silicon availability. The Huron River should be a constant source of many elements, including silica. Interestingly, estimates of biogenic silica did not correspond to the pattern of diatom density and were quite high in the top $25 \mathrm{~cm}$ of the core (Fig. 2); obviously, these observations are not consistent with a hypothesis of silicon limitation.

Numerous other hypotheses might be advanced for the decline in diatom abundance, e.g. introduction of metals and hydrocarbons from industrial sources, changes in turbidity and chloride concentration due to 


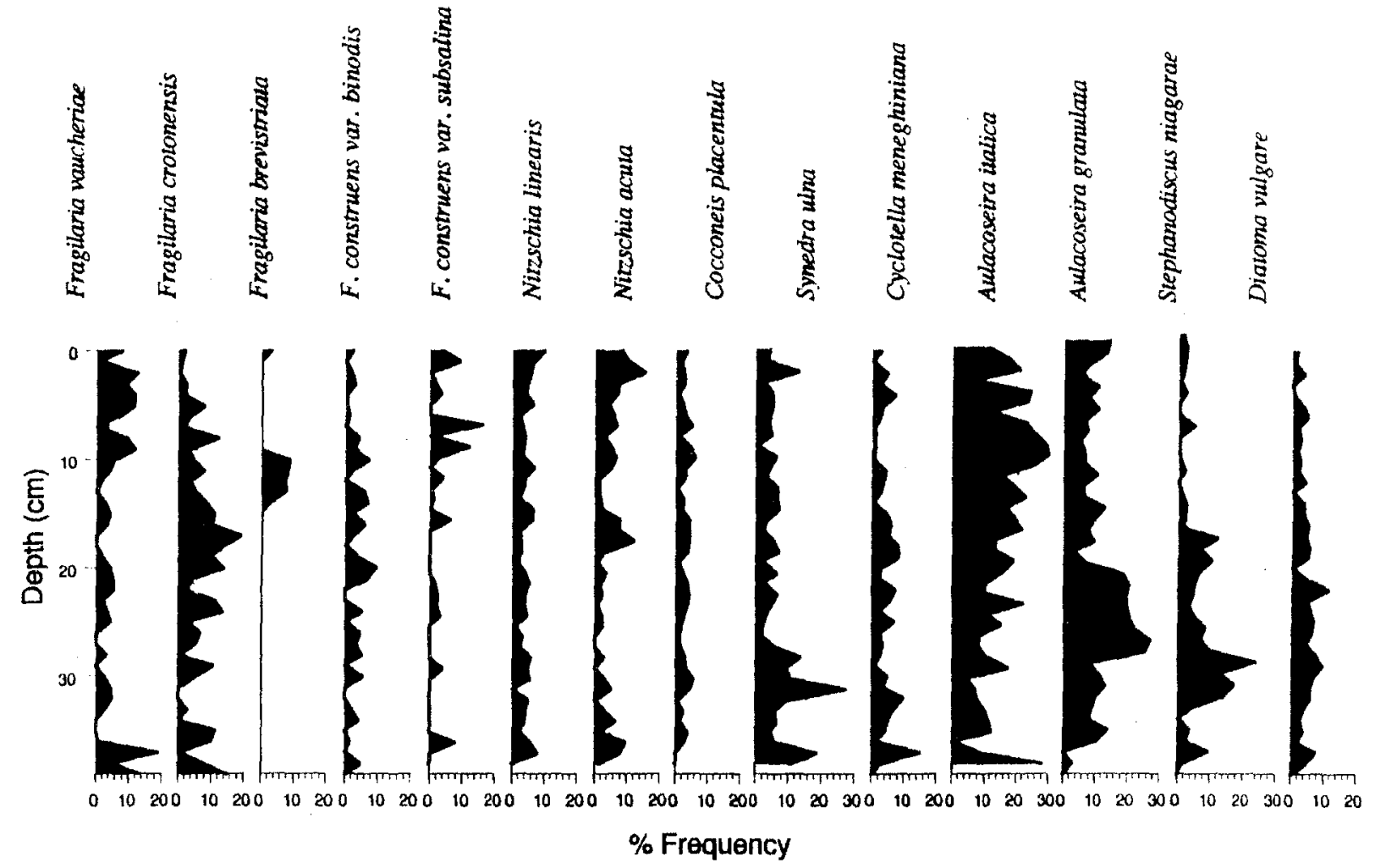

Fig. 4. The percent abundance (per gram of dry sediment) of diatom taxa in a $40 \mathrm{~cm}$ core from Ford Lake reservoir, Michigan, USA.

increased urbanization in the watershed or alleopathic interactions with blue green algae. Some combination of these factors have probably caused the precipitous decline in the density of some major planktonic diatom taxa. This pattern may be characteristic of the response of algal communities in reservoirs to environmental stress from urban and industrial sources. The closing of the Ypsilanti treatment plant and continued efforts by industry to reduce metal and hydrocarbon discharge into Ford Lake reservoir have probably stimulated the recovery of diatom populations in the last ten years (surface to $5 \mathrm{~cm}$ intervals). Further examination of a series of impoundments each with an increasing percentage of urban and industrial land use patterns in their respective watershed areas could help to verify this proposed pattern. We can say with some certainty that the species composition, absolute number of diatoms, biogenic silicon regimes and phosphorus loading rates indicate that Ford Lake reservoir has been eutrophic since its creation.

\section{Acknowledgments}

We would like to sincerely thank Dr Gary Hannan, Dr Julie Wolin, Dr Mark Oemke and other members of the Center for Great Lakes and Aquatic Sciences at the University of Michigan for their assistance, particularly with verification of diatom identifications.

\section{References}

Alaverez-Cobelas, M. \& M. Arauzo, 1994. Phytoplankton responses of varying time scales in a eutrophic reservoir. Arch. Hydrobiol. 40: 69-80.

Baxter, R. M., 1977. Environmental effects of dams and impoundments. Annu. Rev. Ecol. Syst. 8: 255-283.

Carney, H. J., 1982. Algal dynamics and trophic interactions in the recent history of Frains Lake, Michigan. Ecology. 63: 1814-1826.

Davis, C. O. \& M. S. Simmons, 1979. Water chemistry and phytoplankton field and laboratory procedures. University of Michigan, Great Lakes Research Division Special Report Number 70. 73 p.

Dixit, S. S., J. P. Smol, J. C. Kingston, D. F. Charles, 1992. Diatoms: powerful indicators of environmental change. Environ. Sci. Technol. 26: 23-33.

Glover, R. M., 1982. Diatom fragmentation in Grand Traverse Bay, Michigan. Ph.D. thesis, University of Michigan, 204 pp. 
Hustedt, F., 1930. Bacillariophyta. In: Die Süsswasser Flora Mitteleuropas. (herausg. A. Pascher) Heft 10 (Zweite Auflage), $466 \mathrm{pp}$.

Lowe, R., 1974. Environmental requirements and pollution tolerance of freshwater diatoms. U.S.E.P.A. Publication number 670-4-74.

Owen, A. L., 1991. Limnological study including total phosphorus and total organic carbon budgets of Ford Lake reservoir. M.S. Thesis. Eastern Michigan University, 119 pp.

Patrick, R. \& C. W. Reimer, 1966. The Diatoms of the United States. Volume 1. Acad. Nat. Sci. Phila. Monograph number 13.

Smol, J. P., 1987. Methods in Quaternary Ecology. No. 1. Freshwater Algae. Geoscience Canada 14: 208-217.

Soballe, D. M. \& B. L. Kimmel, 1987. A large scale comparison of factors influencing phytoplankton abundance in rivers, lakes, and impoundments. Ecology 68: 1943-1954.
Stoermer, E. F., 1978. Phytoplankton assemblages as indicators of water quality in the Laurentian Great Lakes. Trans. Am. Micro. Soc. 97: 2-16.

Stoermer, E. F., J. A. Wolin, C. L. Schelske \& D. J. Conley, 1985a. An assessment of ecological changes during the recent history of Lake Ontario based on siliceous microfossils preserved in the sediments. J. Phycol. 21: 257-276.

Stoermer, E. F., J. A. Wolin, C. L. Schelske \& D. J. Conley, 1985 b. Variations in Melosira islandica valve morphology related to eutrophication and silica depletion. Limnol. Oceanogr. 30: 414418.

United States Environmental Protection Agency (USEPA) 1975. Report on Ford Lake, Washtenaw County, Michigan. E.P.A. region V. working paper No. 193, National Eutrophication Survey, $14 \mathrm{pp}$. 